\title{
Analysis Effect of Cloud Cover, Wind Speed, and Water Temperature to BOD and DO Concentration Using QUAL2Kw Model (Case Study In Winongo River, Yogyakarta)
}

\author{
Nelly Marlina ${ }^{1,}$, and Dirja Melyta $^{1}$ \\ ${ }^{1}$ Department of Environmental Engineering, Islamic University of Indonesia, Yogyakarta 55584, \\ Indonesia
}

\begin{abstract}
Winongo river is one of the rivers in the province of D.I. Yogyakarta that included in the category of contaminated. the research aims to learn on the effect variation of cloud cover, wind speed, and water temperature on BOD and DO concentrate in order to choose water quality management strategy at Winongo river. This research conducting a simulation with variating the cloud cover variables $(0 \%, 69 \%$, and $88 \%)$, wind velocity $(0 \mathrm{~m} / \mathrm{second}, 0,211 \mathrm{~m} / \mathrm{second}$ and $1,22 \mathrm{~m} / \mathrm{second})$, and so the water temperature air $\left(24,2{ }^{\circ} \mathrm{C}, 28,14{ }^{\circ} \mathrm{C}\right.$, and $\left.30,6{ }^{\circ} \mathrm{C}\right)$. The modeling result shows that cloud cover variables don't affect the DO-BOD concentrate at Winongo river $(\operatorname{sig}=0)$. While the wind velocity variables only have a small effect on the changed of DO and BOD at Winongo river ( $\operatorname{sig}>0,05)$. And for water temperature variables had the significant effect on the concentration changed of DO $(\mathrm{sig}<0,05)$ and have a small effect on the changed of BOD at Winongo river (sig $>0,05$ ). The DO and BOD management strategy can be done by making of riparian buffer strips or planting vegetation on the riverbank Winongo, build a WWTP Communal in every district along the river Winongo
\end{abstract}

Keywords: Cloud cover; Wind speed; Water Temperature; BOD; DO

\section{Introduction}

The Winongo river is one of the rivers in the province of D.I. Yogyakarta that included in the category of contaminated. Winongo River is a tributary Opak with a length of 48.70 $\mathrm{km}$, which has headwaters in the village Girikerto Turi district, Sleman and empties into the river Opak Ivory, Donotirto Village, Kretek District, Bantul. The existence of the river that divides the urban Yogyakarta Winongo increase the potential for contamination in Winongo. Potential pollutant sources in Winongo comes from residential, office, public and industrial facilities.

The decline in water quality can be determined by measurement of water quality parameters including measurement of Dissolved Oxygen (DO) and BOD (Biochemical

* Corresponding author: nelly.marlina@uii.ac.id 
Oxygen Demand). Parameters DO is a common indicator that shows the health of the waters [1]. Parameter BOD is one of the key variables were used to evaluate the quality of river water [2].

The existence of DO and BOD in the waters affected by the heat balance is affected by cloud cover, air temperature, wind speed, water temperature, mass balance associated with the ingredients contained in the river, and the materials that go into the river and out of rivers, streams and hydrological factors such as river discharge [3].

Based on the above, the study aims to assess the effects of cloud cover, wind speed, and temperature of the water to the concentration of DO and BOD use QUAL2Kw in order to determine water quality management strategy in Winongo.

\section{Method}

\subsection{Description of Qual2Kw}

Qual2Kw is a river and stream water quality model. In the Qual2Kw model, the River is divided into several reaches which represent stretches of river that have constant hydraulic characteristics (e.g., slope,bottom width,etc). the main input data are geometric properties of the river (e.g Channel slope,channel width,Manning roughness coefficient,etc), flow rate,pollutant loads, and meteorological parameters. Qual2Kw considering the condition of climatologist because it can affect the balance of the heat that would have an impact on water quality conditions that will be modeled. Heat equilibrium in an element is illustrated in Figure 1.1 and can be expressed in the following equation

$$
\begin{aligned}
\frac{d T_{i}}{d t}=\frac{Q_{i-1}}{V_{i}} T_{i-1}-\frac{Q_{i}}{V_{i}} & T_{i}-\frac{Q_{a b, i}}{V_{i}} T_{i}+\frac{E_{i-1}^{\prime}}{V_{i}}\left(T_{i-1}-T_{i}\right)+\frac{E_{i}^{\prime}}{V_{i}}\left(T_{i+1}-T_{i}\right) \\
& +\frac{W_{h, i}}{\rho_{w} C_{p w} V_{i}}\left(\frac{\mathrm{m}^{3}}{10^{6} \mathrm{~cm}^{3}}\right)+\frac{J_{h, i}}{\rho_{w} C_{p w} H_{i}}\left(\frac{\mathrm{m}}{100 \mathrm{~cm}}\right)+\frac{J_{s, i}}{\rho_{w} C_{p w} H_{i}}\left(\frac{\mathrm{m}}{100 \mathrm{~cm}}\right)
\end{aligned}
$$

where $T_{i}=$ temperature in reach $i\left[{ }^{\circ} \mathrm{C}\right], t=$ time [d], $E^{\prime}{ }_{i}=$ the bulk dispersion coefficient between reaches $i$ and $i+1\left[\mathrm{~m}^{3} / \mathrm{d}\right], W_{h, i}=$ the net heat load from point and non-point sources into reach $i[\mathrm{cal} / \mathrm{d}], \rho_{w}=$ the density of water $\left[\mathrm{g} / \mathrm{cm}^{3}\right], C_{p w}=$ the specific heat of water $[\mathrm{cal} /(\mathrm{g}$ $\left.\left.{ }^{\circ} \mathrm{C}\right)\right], J_{h, i}=$ the air-water heat flux $\left[\mathrm{cal} /\left(\mathrm{cm}^{2} \mathrm{~d}\right)\right]$, and $J_{s, i}=$ the sediment-water heat flux [cal $\left./\left(\mathrm{cm}^{2} \mathrm{~d}\right)\right]$. [3]

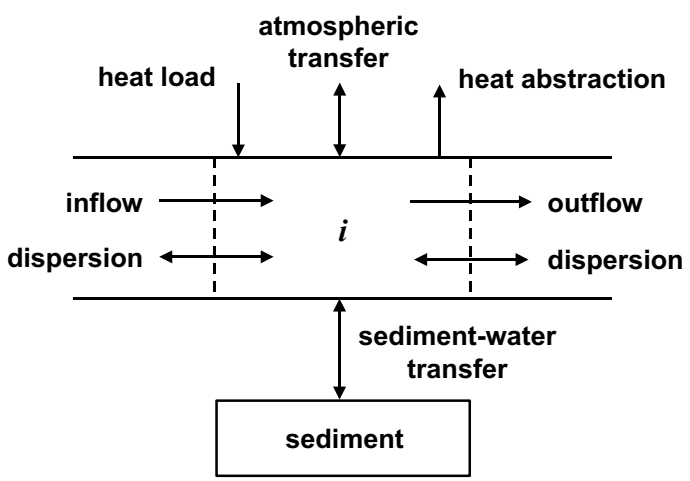

Fig. 1. Heat balance 


\subsection{Segmentation of the River}

Winongo River is a tributary Opak with a length of $48.70 \mathrm{~km}$ (Fig 1), which has headwaters in the village Girikerto Turi district, Sleman and empties into the river Opak Ivory, Donotirto Village, Kretek District, Bantul. The existence of the river that divides the urban Yogyakarta Winongo increase the potential for contamination in Winongo. Potential pollutant sources in Winongo comes from residential, office, public and industrial facilities.

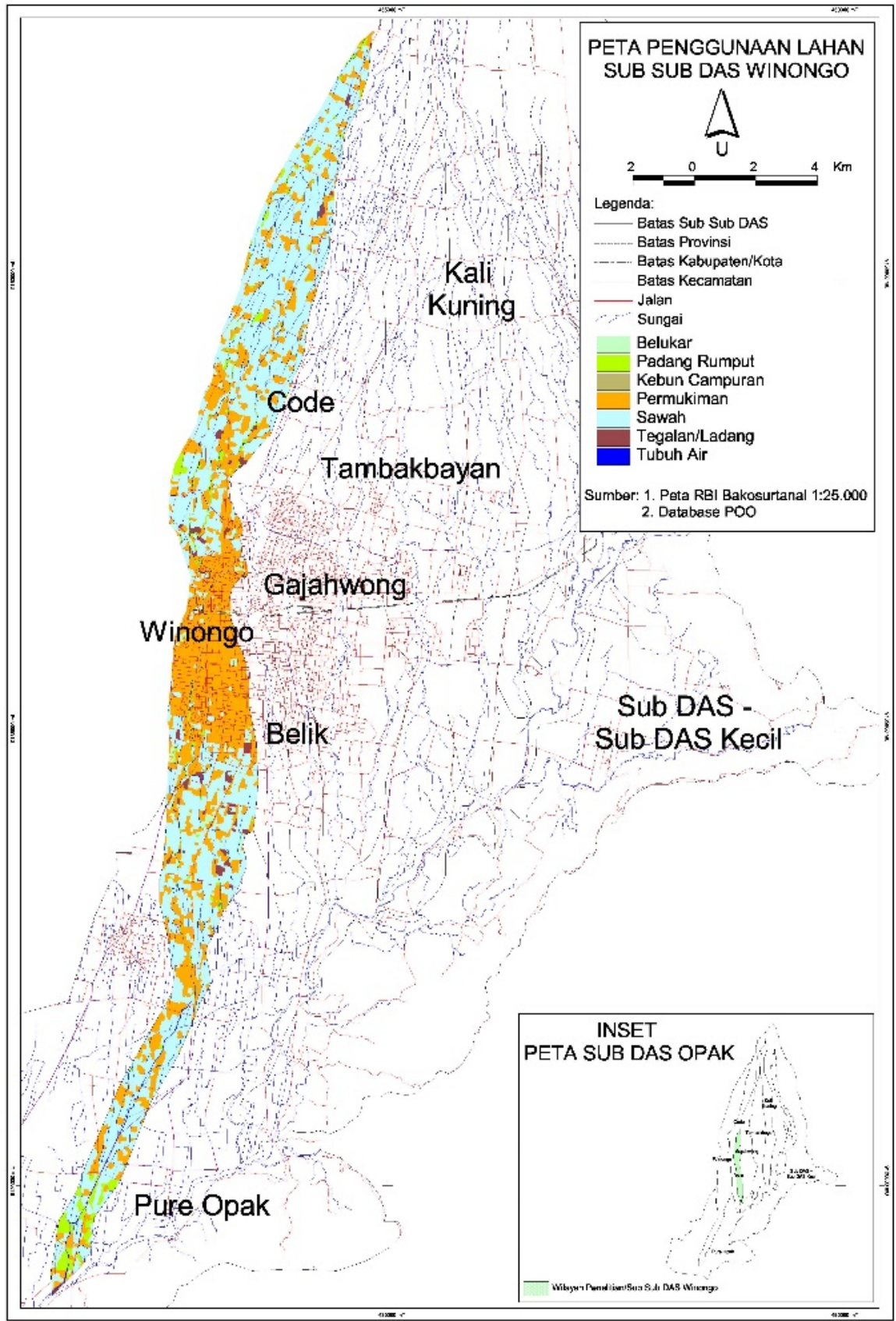

Fig 2. Study of area 


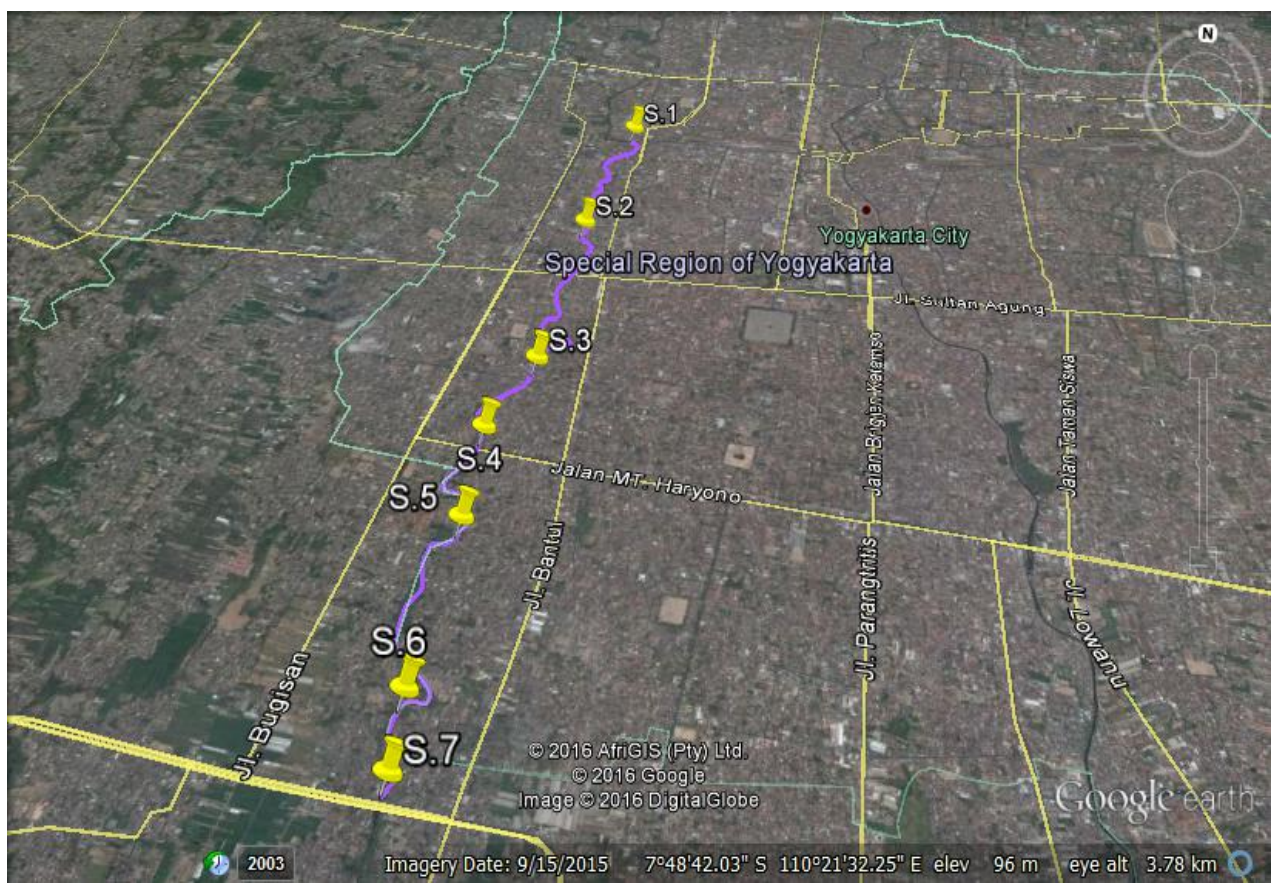

Fig 3. Location of sampling points

Table 1. Apportionment of River Sections.

\begin{tabular}{|c|c|c|c|c|c|}
\hline \multirow{2}{*}{ Segment } & \multirow{2}{*}{ Upstream-Downstream } & \multirow{2}{*}{ Code } & \multirow{2}{*}{$\begin{array}{l}\text { Length } \\
(\mathbf{k m})\end{array}$} & \multicolumn{2}{|c|}{ Elevation (m) } \\
\hline & & & & Upstream & $\begin{array}{c}\text { Downstrea } \\
\text { m }\end{array}$ \\
\hline 1 & Jlagran-Pendowo & S1-S2 & 1,136 & 117 & 114 \\
\hline 2 & Pendowo-Tamansari & $\mathrm{S} 2-\mathrm{S} 3$ & 1,406 & 114 & 108 \\
\hline 3 & Tamansari-Sugeng Jeroni & S3-S4 & 0,563 & 108 & 101 \\
\hline 4 & Sugeng Jeroni-Prapanca & S4-S5 & 0,666 & 101 & 99 \\
\hline 5 & Prapanca-Dukuh & S5-S6 & 1,066 & 99 & 96 \\
\hline 6 & Dukuh-Dongkelan & S6-S7 & 0,362 & 96 & 95 \\
\hline
\end{tabular}

\subsection{Analysis Sensitivity}

The simplest method in the sensitivity analysis is to replace the variable values in terms of sensitivity and let the value of other variables remain. By observing changes in the results 
of the model that happens, we can compare the sensitivity of the model to other variables are treated alike [4].

\subsection{Calibration}

Calibration is the process of determining the most appropriate coefficient, so the comparison of model results with field data shows the price of the most well reviewed statistically significant [5]. Uji calibration or test of the ability of forecast models to obtain the value of variables - variables in the model generally the specific location [4].

\subsection{Validation}

The purpose of validation is to determine the suitability of the model is produced with water quality data that were previously used as input in the modeling process. The validation process was conducted using Percent Root Mean Square Error (RMSPE) which measures the average percentage difference between actual data and simulation results, using the formula:

$$
\text { RMSPE }=\sqrt{\frac{1}{n}\left[\sum_{n=1}^{n}\left(\frac{S t-A t}{A t}\right)^{2}\right]} \times 100 \%
$$

Description:

RMSPE: Root Mean Square Percent Error

St: Simulation value at time $\mathrm{t}$

At: The actual value at time $\mathrm{t}$

$\mathrm{n}$ : Number of observations $(\mathrm{t}=1,2, \ldots ., \mathrm{n})$

\subsection{Simulation Models}

Table 2. Simulation Models

\begin{tabular}{cccc}
\hline Scenario & \multicolumn{3}{c}{ Variation in Data Simulation } \\
& Minimum & Maximum & Average \\
\hline Scenario 1: Cloud Cover & $0 \%$ & $88 \%$ & $60 \%$ \\
Scenario 2: Wind Speed & $0 \mathrm{~m} / \mathrm{s}$ & $1,22 \mathrm{~m} / \mathrm{s}$ & $0,211 \mathrm{~m} / \mathrm{s}$ \\
Scenario 3: Water Temperature & $24,2{ }^{\circ} \mathrm{C}$ & $30,6{ }^{\circ} \mathrm{C}$ & $28,14{ }^{\circ} \mathrm{C}$ \\
\hline
\end{tabular}

\section{Results and Discussion}

The Division of the River segment to measure the average percentage difference between the actual data and simulation results, then the validation is done by using the method of the Root Mean Square Errors (RMSPE) Percent. Test the validity of the calculation results with method RMSPE, pointed out that the validity of the data model with data field for parameters $\mathrm{DO}$ is $11 \%$ and for parameters of $\mathrm{BOD}$ of $9 \%$. The results showed that the 
model approaches the actual circumstances ( $\mathrm{R}$ or $\mathrm{R} 0.5<<50 \%$ ), so that the model can be used for the simulation of scenarios.

Cloud cover influence on DO and BOD (Scenario 1)

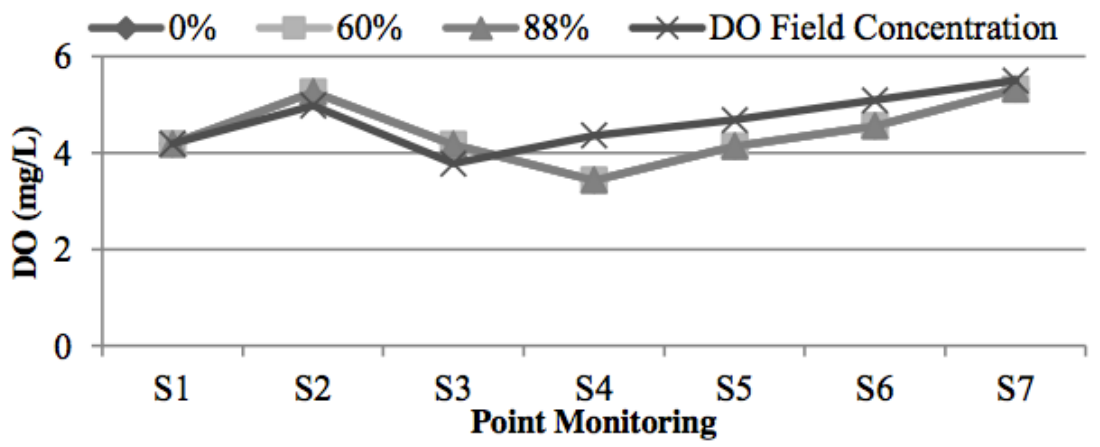

(a)

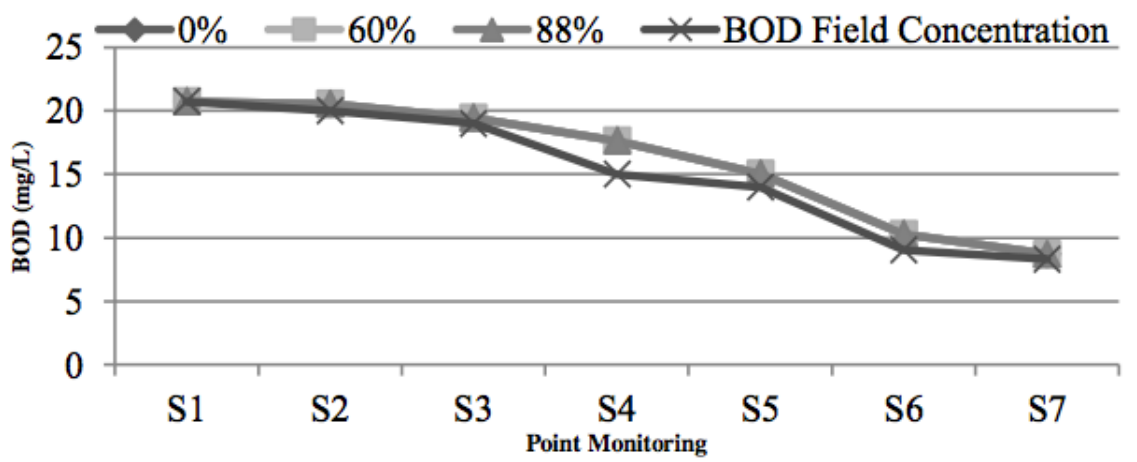

(b)

Fig. 4. The influence of the percentage of cloud cover variation to changes in the concentration of DO (a) and BOD (b)

Based on Figure 1 shows that the cloud cover to give effect to changes in the concentration of DO and BOD water Winongo when compared to baseline prior to the simulation. However, these effects did not experience any difference in each variation of cloud cover. This condition indicates that the variation of cloud cover does not have a significant influence on the distribution of DO and BOD concentration Winongo River water. $\mathrm{T}$ where based on test results or different test parameters for DO and BOD indicates that the count value $\mathrm{T}$ and $\mathrm{T}$ table value is equal to 0 , which means there is no difference in the value of any variation of cloud cover. Cloud cover affects only the amount of solar radiation received by the Earth's surface and is not dominant variables that directly influence changes in the concentration of DO and BOD in the water.

Although cloud cover affects solar radiation emitted into the Earth's surface, more or less sunlight received can vary according to place and time. Model Qual2Kw calculate the amount of solar radiation into the water is adjusted to the latitude and longitude of a location [3]. The amount of solar radiation by the model are calculated as the earth's upper atmosphere radiation are reduced by clouds, shade, reflection and obstacles atmosphere [3]. The amount of radiation reaching the surface of the waters is affected by clouds, altitude (altitude), geographical location, and season [6]. Light penetration into the water is strongly influenced by the intensity and angle of incidence of light, water level, and the ingredients 
are dissolved and suspended in water [6]. The angle of incidence of sunlight to the surface of the water varies daily. At an incidence angle of exactly $90^{\circ} \mathrm{C}$ (occurred at around 12:00) sunlight reflected about $1.5 \%-2.0 \%$. The smaller the angle of incidence of light, the more light is reflected [6]. The intensity of the light reflected by the surface of the water also varies according to the season, where the dry season the intensity of sunlight reaching the surface of the water is greater than in the rainy season [6].

Effect of Wind Speed to DO and BOD (Scenario 2)

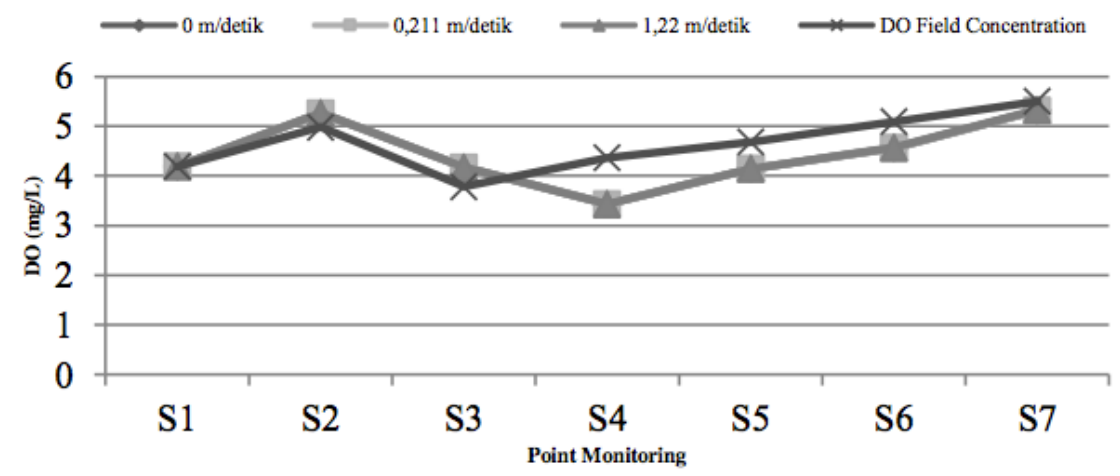

(a)

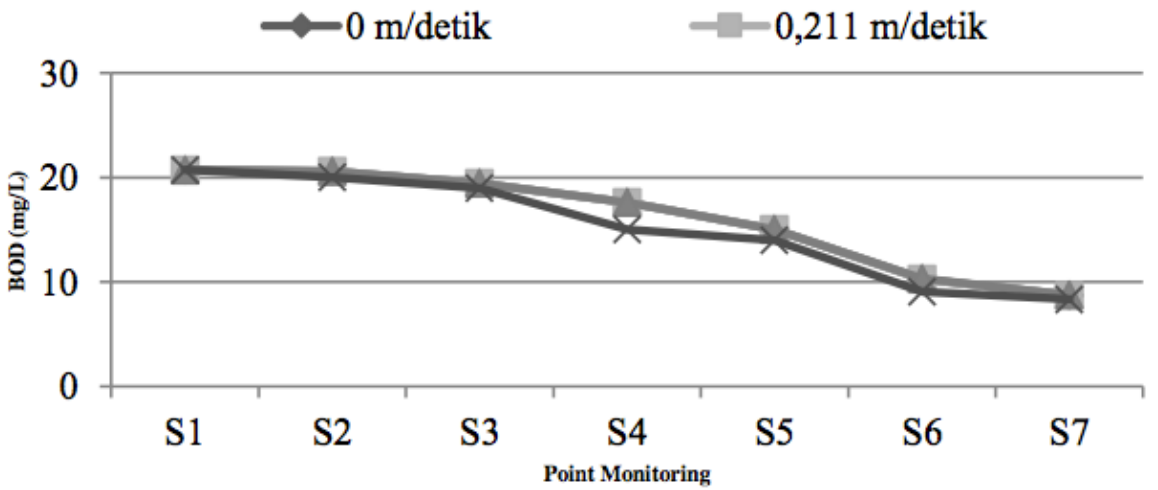

(b)

Fig. 5. Effect of wind speed variation to changes in the concentration of DO (a) and BOD (b)

Based on Figure 2 can be seen that the variation in wind speed affects the concentration of DO and BOD Winongo river water. But the change is not significant where based on test $\mathrm{T}$ or different test showed sig $>0,05$. Wind speed affects the transfer of heat flow into the river, causing changes in water temperature. The temperature of the water will affect the concentration of $\mathrm{DO}$ and $\mathrm{BOD}$ of the river water.

According to Nurlina (2012) [7], the wind speed is likely to cause the potential for heat flow into the river to be reduced, so that the water temperature tends to be lower. This situation causes the solubility of oxygen is increased so that the increase in the concentration of DO tend to be larger. At the BOD, if the greater the wind speed, water temperature tends to be lower so that the reaction rate of degradation of organic material is getting too small. Therefore, the greater the wind speed, reduction in BOD concentrations from upstream to downstream tend to be smaller. 
Effect of River Water Temperature to DO and BOD (Scenario 3)

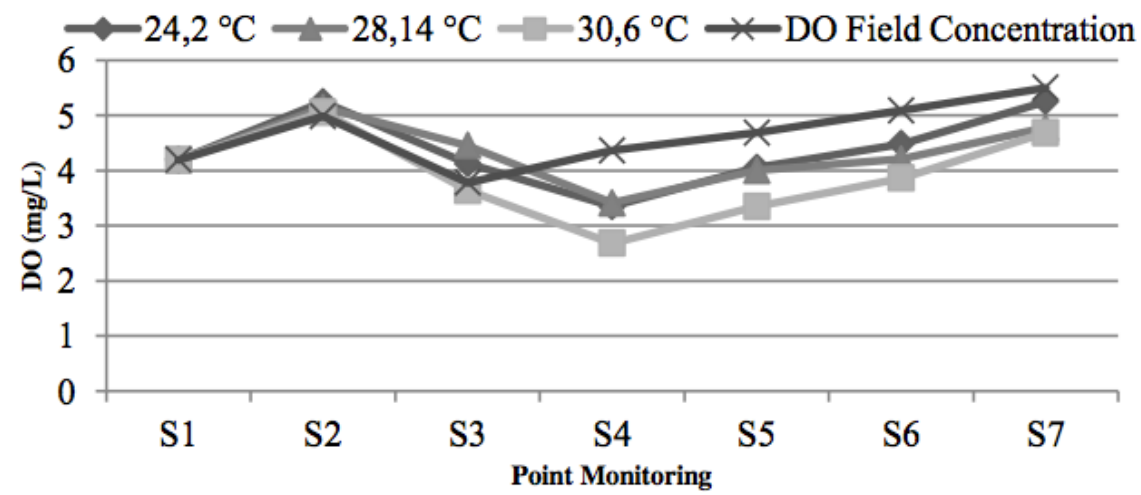

(a)

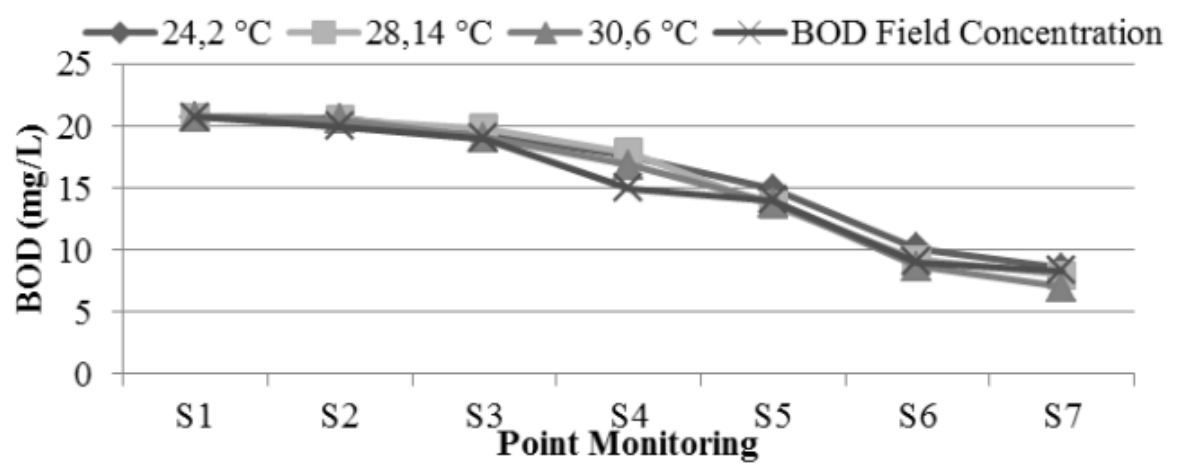

(b)

Fig. 6. The influence of water temperature variation to changes in the concentration of DO (a) and BOD (b)

Based on Figure 3 is known that variations in water temperature affect the change in concentration of DO and BOD from upstream to downstream. T-test results or showing different test parameter values for DO sig $<0.05$, which means the concentration of DO from upstream to downstream undergo significant changes at each water temperature variations. As for the BOD, test results or test different $\mathrm{T}$ showed sig $>0.05$, which means that the BOD concentration from upstream to downstream in each variation of water temperature changes were not significant. Increasing the concentration of DO from upstream to downstream tend to be smaller with increasing temperature. Conversely, a decrease in BOD concentrations from upstream to downstream tends to be greater with increasing temperature.

Temperature can affect the speed of chemical reactions in the water, aquatic plants photosynthesis rate, the rate of metabolism and affect the interaction of pollutants, parasites, and other pathogens creature with water. The chemical reaction increases with the increase in water temperature so that temperature affected the rate of $\mathrm{DO}$, dissolved oxygen and the reaction rate of degradation/deoxygenation (BOD degradation by microbes) [7].

The increase in temperature causes an increase in metabolic rate and respiration of aquatic organisms, and subsequently result in increased oxygen consumption so that changes in the increase in DO tend to be smaller. Decreased levels of dissolved oxygen due to the increase in temperature causes the presence of oxygen are often unable to meet the oxygen requirements for aquatic 
organisms to make the process of metabolism and respiration. The increase in water temperature of $10^{\circ} \mathrm{C}$ causes an increase in oxygen consumption by aquatic organisms are approximately 2-3 fold [6]. Higher temperatures can lead to an increase in organic matter decomposition by microbes, so the reduction in BOD concentrations from upstream to downstream likely to be.

DO and BOD management strategies in Winongo to do with the making of riparian buffer strips or planting vegetation on the riverbank Winongo. Vegetation in the area of riparian has several functions: to control erosion, to protect surface waters, especially in terms of preventing water temperatures, as catcher sediments, help increase groundwater supplies, as a place of life and the diversity of flora and fauna, and as aesthetic boundaries of settlements and construction[8].

The vegetation is planted with trees in the surrounding watershed can provide aesthetic value and useful in curbing the rate of erosion of the run-off as well as lowering the air temperature in the watershed [9]. Vegetation makes electromagnetic wave radiation from the sun is blocked so that the amount of radiation that the river water is reduced and cause a decrease in water temperature of the river [9]. By decreasing the temperature of the river water will increase the solubility of oxygen so that changes in the increase of DO likely to be.

The vegetation along the river could increase the activity of photosynthesis, which is the main source of oxygen in the water. In the process of photosynthesis, carbon dioxide is reduced to carbohydrates and water undergoes dehydrogenation into oxygen [7].

In addition, riparian vegetation can cause a body of water turbulence or turbulence of the mass of water so as to improve the process of diffusion of oxygen from the atmosphere into the water. With increasing concentration of dissolved oxygen (DO), the process of decomposition of organic material by microorganisms can take place properly, so the reduction in BOD concentrations from upstream to downstream likely to be.

Decomposition of organic materials can reduce the levels of dissolved oxygen. Therefore, there should be efforts to reduce organic pollution load originating from industrial and domestic waste. Efforts to reduce the influx of organic pollutant load along Winongo can be done by making communal WWTP in each of the districts in Winongo. In the communal WWTP will be a process of degradation of organic material so as to reduce the pollution load of organic materials that went into the river and needs oxygen required to degrade organic matter is also getting smaller.

In addition, efforts to tightening the quality standards of industrial and domestic waste also need to be done to reduce the pollution load in the river Winongo.

\section{Conclusion}

Variables that influence the change in the concentration of DO-BOD Winongo is the wind speed and water temperature, while variable cloud cover has no effect. The greater the wind speed, the increase in the concentration of DO tend to be bigger, otherwise decrease BOD concentrations tend to be smaller. The greater the temperature of the river water, the increase in the concentration of DO tend to be smaller, while the decline in BOD concentrations from upstream to downstream likely to be.

The DO and BOD management strategy can be done by making of riparian buffer strips or planting vegetation on the riverbank Winongo, build a WWTP Communal in every district along the river Winongo, and tightening Wastewater Quality Standard for industrial and domestic activities which should not exceed the class II Air Quality Standard. 


\section{References}

1. Hammond, D.G., Evaluating Dissolved Oxygen Regimes Along a Gradient of Human Disturbance for Lotic Systems in West-Central Florida, Theses and Dissertations, University of South Florida, Florida. (2009)

2. Ravelli, R. And Ridolfi, L, Stochastic Dynamics of BOD in A Stream with Random Inputs, AWR (2004)

3. Chapra. S.C. dan Pelletier, ZG, QUAL2K: A Modeling Framework for Simulating River and Stream Water Quality (Version 2.11): Documentation and User Manual, Civil and Environmental Engineering Dept., Tufts University, Medford, MA (2006)

4. Notodarmojo, Suprihanto. Soil and Groundwater Pollution. ITB, Bandung (2005)

5. Schnoor, Jerald L. Environmental Modeling, Fate, and Transport of Pollution in Water, Air, and Soil.John Wiley, New York, (1996)

6. Effendi, H. Assessing Water Quality For Management of Water Resources and Environment. Publisher Canisius, Yogyakarta (2003).

7. Nurlina. Studies Concentration Changes DO and BOD As well as Factors Affecting the QUAL2K Modeling (Case Study Kapuas River in West Kalimantan). S2 Chemical Sciences, University of Gadjah Mada, Yogyakarta. (2012)

8. Keppy, Meiske. Riparian Vegetation structure Winongo in Bantul. Undergraduate thesis, Duta Wacana Christian University. (2004)

9. Lestari, A. Dyah Novitasari. Study Effect of Hydraulics, Shade, and Point Source Of River DO-BOD Using QUAL2Kw Model (Case Study: Rivers Gajahwong, Yogyakarta ). S2 Chemical Sciences, University of Gadjah Mada, Yogyakarta. ( 2012) 